\title{
A Case of Compartment Syndrome and Rhabdomyolysis After Alcohol Consumption
}

\author{
Alkol Kullanımı Sonrası Gelişen Kompartman Sendromu ve Rabdomiyoliz Olgusu
}

(1) Arife Çimen Atalar, (1) Cansu Söylemez, (1) Fergane Memmedova, (1) Ufuk Emre

Istanbul Training and Research Hospital, Clinic of Neurology, Istanbul, Turkey

Keywords: Compartment syndrome, alcohol, rhabdomyolisis

Anahtar Kelimeler: Kompartman sendromu, alkol, rabdomiyoliz

\section{Dear Editor,}

Compartment syndrome (CS) is defined as impaired perfusion of tissue capillaries due to increased perfusion pressure in muscle fascias of the extremities and can lead to rhabdomyolysis (1). Damage in muscles disturbs normal circulation by causing edema and leads to severe edema in extremities, stiffness of muscles by palpation, and severe pain. Necrosis of muscles causes increase in creatinine kinase (CK), aspartate aminotransferase (AST), alanine aminotransferase (ALT), lactate dehydrogenase (LDH) levels, and results in myoglobinuria. Bone fractures, long-term compression, burns, and extreme exercise are the causes of this rare syndrome.

A 35-year-old male was admitted to the emergency room with pain in the legs and difficulty in walking after staying on his knees for a long time following alcohol consumption. The patient had weakness in the legs and difficulty in walking. A general and neurologic examination showed severe edema, stiffness, and rash in the legs and severe paraparesis predominantly affecting the distal lower extremities with a significant decrease in deep tendon reflexes. No flow was observed in the bilateral popliteal veins in venous Doppler ultrasonography performed in the emergency room which was thought to be secondary to compression. Findings in the bilateral cruris magnetic resonance imaging were compatible with rhabdomyolysis and myositis. AST: 2832 U/L, LDH: 2209 U/L, CK: $167250 \mathrm{U} / \mathrm{L}$ and myoglobinuria were detected. The patient was diagnosed as having rhabdomyolysis secondary to CS causing acute renal failure and acute hemodialysis was performed. The laboratory findings improved following dialysis (AST: 68 U/L, ALT: 221U/L, LDH: 527 U/L, CK: 1067 U/L).
Electromyography (EMG) performed in the early period to investigate paraparesis showed asymmetric sensorimotor axonal polyneuropathy in the lower extremities and myopathic involvement. The patient was followed up on the ward because of continuing weakness in the legs. Follow-up EMG performed 3 weeks after symptom onset showed bilateral but leftpredominant axonal damage in the tibial and common peroneal nerves. Steroid treatment was initiated due to remaining symptoms despite resting and analgesic treatment. The pain was improved in the follow-up and at 6 months after discharge neurologic examination showed only weakness in dorsiflexion of the left lower extremity. The first year neurologic examination was normal.

Alcohol can lead to alcoholic myopathy through the toxic and direct effect of ethanol or by causing a lack of nutrition secondarily in acute, subacute or chronic consumption. Also, chronic consumption of alcohol causes inflammation in muscles, which can result in CS or rhabdomyolysis (2). Rhabdomyolysis is an important cause of acute renal failure and is not considered in the differential diagnosis in many cases. Some data about the relationship between alcohol and rhabdomyolysis were revealed by studies from Japan $(3,4)$. All the patients were unconscious for hours and had rhabdomyolysis due to compression necrosis, and one developed acute renal failure. In $33 \%$ of the patients reported in the literature, rhabdomyolysis resulted in acute renal failure $(3,4,5)$. Hypovolemia caused by rhabdomyolysis or the direct toxic effect of myoglobulin causes acute renal failure. Commonly, rhabdomyolysis affects anterior or deep posterior compartments

Address for Correspondence/Yazışma Adresi: Arife Çimen Atalar MD, Istanbul Training and Research Hospital, Clinic of Neurology, Istanbul, Turkey Phone: +90 2124596000 E-mail: cimenatalar@yahoo.com.tr ORCID ID: orcid.org/0000-0003-0328-9607

Received/Geliss Tarihi: 29.03.2016 Accepted/Kabul Tarihi: 20.11.2017

${ }^{\circ}$ Copyright 2018 by Turkish Neurological Society

Turkish Journal of Neurology published by Galenos Publishing House. 
in the lower extremities or the antebrachial volar compartment in upper extremities (3). The most common causes are fractures and soft tissue traumas. Other causes are spontaneous hemorrhage due to hemophilia, long-term compression of extremities caused by unconsciousness due to drug over use or alcohol comsumption, infection, burns, edema due to insect bites, edema due to revascularization after arterial trauma, external compression due to unprotected positioning of an extremity in long-duration surgery, applying a long-duration surgical tourniquet, and vascular puncture in patients using anticoagulant therapy (4). Early and aggressive dehydration and acute dialysis if needed should be performed in patients with rhabdomyolysis and acute renal failure.

As a result, CS due to alcohol abuse should be kept in mind in the differential diagnosis of some life-threating conditions as rhabdomyolysis and acute renal failure.

Evaluation of early electrophysiologic findings with clinical findings and long-term follow-up of patients are required.

Ethics

Informed Consent: Consent form was filled out by all participants.

Peer-review: Internally peer-reviewed.

\section{Authorship Contributions}

Medical Practice: C.S., F.M., Design: A.Ç.A., Data Collection or Processing: A.Ç.A., Analysis or Interpretation: A.Ç.A., U.E., Literature Search: A.Ç.A., C.S., F.M., Writing: A.Ç.A., C.S.

Conflict of Interest: No conflict of interest was declared by the authors.

Financial Disclosure: The authors declared that this study received no financial support.

\section{References}

1. Farrow C, Bodenham A, Troxler M. Acute limb compartment syndromes. Continuing Education in Anesthesia, Critical Care \& Pain 2011;11:24-28.

2. Whitesides TE, Heckman MM. Acute Compartment Syndrome: Update on Diagnosis and Treatment. J Am Acad Orthop Surg 1996;4:209-218.

3. Daher Ede F, Silva Júnior GB, Brunetta DM, Pontes LB, Bezerra GP. Rhabdomyolysis and acute renal failure after strenuous exercise and alcohol abuse: case report and literature review. San Paulo Med J 2005;123:33-37.

4. Wai K, Thompson PD, Kimber TE. Fashion victim: rhabdomyolysis and bilateral peroneal and tibial neuropathies as a result of squatting in 'skinny jeans'. J Neurol Neurosurg Psychiatry 2016;87:782.

5. Botte MJ, Gelberman RH. Compartment syndrome and ischemic contracture. In: Nickel VL, Botte MJ, editors. Orthopaedic rehabilitation. 2nd ed. New York, CN: Churchill Livingstone Inc; 1992.p.629-643. 